\title{
Childcare Physical Activity Interventions: A Discussion of Similarities and Differences and Trends, Issues, and Recommendations
}

\author{
Rachel A. Jones* * Eduarda Sousa-Sá ${ }^{\circ}$, Michele Peden and Anthony D. Okely® \\ Early Start, University of Wollongong, Northfields Ave, Wollongong, NSW 2522, Australia; \\ emdsr885@uowmail.edu.au (E.S.-S.); mep948@uowmail.edu.au (M.P.); tokely@uow.edu.au (A.D.O.) \\ * Correspondence: rachelj@uow.edu.au
}

Received: 15 October 2019; Accepted: 25 November 2019; Published: 2 December 2019

check for updates

\begin{abstract}
Early childhood education and care (ECEC) settings have a pivotal role in the promotion of physical activity for young children, and thus, the number of ECEC-based physical activity interventions has exponentially increased in the last two decades. The aim of this study was three-fold: (1) to discuss some of the similarities and differences in ECEC-based physical activity interventions, (2) to highlight current trends and issues in the ECEC sector relating to such interventions, and (3) to provide recommendations for future interventions. Twenty-four individual studies are discussed. Most studies have targeted children aged between 3 and 5 years and involved children participating in additional physical activity opportunities while at childcare. In all studies, educators participated in some professional development either prior or during the intervention. Less the half of the studies discussed reported significant positive changes in physical activity outcomes. Those involved in developing future interventions will need to consider current national and international trends in the ECEC sector (e.g., over-crowded curriculum, administrative requirements, and more highly-qualified educators devoting time for business development), as well as creative and unique ways of delivering ECEC-based physical activity interventions.
\end{abstract}

Keywords: physical activity; early childhood education and care settings; professional development; interventions; preschool children

\section{Introduction}

Healthy physical activity habits need to be established from a young age to ensure optimal health, well-being, and development [1]. Furthermore, the promotion of physical activity should start as early as possible, as physical activity levels track from early childhood to childhood and adolescence [2]. The early childhood education and care (ECEC) setting has been identified as a critical setting for the promotion of physical activity and physical activity-related behaviors [3]. The ECEC setting is critical in the promotion of these behaviors, because many children across the globe spend more awake time in these settings compared to other settings. In some countries, children spend seven to eight hours in such settings, five days a week [4].

Current data suggests that approximately $50 \%$ of children whilst attending ECEC do not meet the recommended levels of physical activity ( $15 \mathrm{~min} / \mathrm{h}$ for every hour of care), and spend up to $50 \%$ of their time in sedentary activities [5]. To combat these less-than-optimal trends in physical activity, the number of ECEC-based physical activity interventions have steadily increased over the past two decades. Consequently, a number of systematic reviews have been published. These reviews have varied in focus, number, and type of studies and analyses. For example, Engel et al. [6] reported on studies that had evaluated the relationship between fundamental motor skills and physical activity, 
whilst Timmons et al. [7] included studies that reported physical activity and health outcomes. Ward, et al. [8] included studies that investigated the relationship between educator behaviors and physical activity. Gordon et al. [9] and Finch et al.'s [10] reviews were both inclusive of meta-analyses.

These reviews provide some high-level recommendations for future ECEC-based interventions, (e.g., reporting of cost data and consideration of sustainability $[10,11])$; however, they generally do not provide recommendations in light of current trends and issues within ECEC sector. Therefore, this discussion piece was completed with the aim of providing a high-level overview of some of the key ECEC-based physical activity interventions, and in turn, highlighting future recommendations for such interventions in light of the current trends and issues within the ECEC sector. This discussion aimed to provide a useable and accessible document that provides realistic and innovative recommendations for future practice.

\section{Materials and Methods}

The studies discussed were sourced from 10 systematic reviews, published between 2009 and 2018 [6-15]. These studies broadly represent the current evidence and meet the following four criterium: (1) focused on physical activity exclusively, or had a physical activity component (i.e., those with a focus on obesity prevention); (2) were delivered in an ECEC setting; (3) were a randomized controlled trial (RCTs), pilot RCTs, cluster RCTs, or quasi-experimental trials; (4) assessed physical activity either subjectively or objectively, and reported physical activity intensity was chosen to be included in the discussion paper. Data such as sample size, length of intervention, intervention components, facilitators of the interventions, type of professional development delivered, instruments used to measure physical activity, and physical activity outcomes were extracted to provide an overall picture of ECEC interventions within the current literature, and to enable discussion pertaining to similarities and differences. The studies included within this paper were not exhaustive, but rather representative of the current evidence. Data from studies were extracted by three researchers (R.A.J., E.S., and M.P.).

\section{Results}

The results section highlights some of the similarities and differences between the identified studies. The study characteristics of the 24 studies identified are highlighted in Table 1. Eighteen studies $(75 \%)$ had physical activity as the primary outcome [16-33], and six $(29 \%)$ had physical activity as a secondary outcome (i.e., the main outcome was another outcome-for example, weight-related outcomes) [34-39]. Studies were conducted in a number of different countries, including the United States $(n=10)$ [16-20,30,33,35-37], Switzerland $(n=2)$ [21,31], Belgium $(n=2)$ [22,24], Germany $(n=2)[23,24]$, Israel $(n=2)[34,38]$, Australia $(n=3)[25,27,28]$, Canada $(n=1)$ [26] and the United Kingdom $(n=2)$ [29,39]. Most studies targeted children aged between three and five years. All but three studies recruited children from non-specialized populations $[16,19,35,36]$. The sample size ranged from 21 to 826 participants, with six studies recruiting less than 100 participants at baseline [16-18,26,27,30].

The interventions ranged from four weeks to one year (pre-test to post-test), and a nearly a third of the studies $(7 / 24,29 \%)$ included a follow-up period (i.e., data were collected at three time points: pre-test, post-test, and follow-up) $[24,29,31,35,36,38,39]$. Three studies included a follow-up time point beyond one year $[35,36,38]$. 
Table 1. Study characteristics included in the overview of reviews.

\begin{tabular}{|c|c|c|c|c|c|}
\hline Reference and Country & $\begin{array}{l}\text { Design, Sample at } \\
\text { Baseline }\end{array}$ & $\begin{array}{l}\text { Length and } \\
\text { Follow-Up }\end{array}$ & Intervention & $\begin{array}{c}\text { PA Outcome/PA } \\
\text { Measurement }\end{array}$ & PA Findings \\
\hline $\begin{array}{l}\text { Alhassan et al., 2007 } \\
\text { United States [16] }\end{array}$ & Pilot RCT, 32 (3.6 yrs) & $3 \mathrm{mths}$ & $\begin{array}{c}2 \times 30 \text { min outdoor play sessions per day, } \\
2 / \mathrm{wk}\end{array}$ & $\begin{array}{c}\text { Primary/ } \\
\text { Accelerometers }\end{array}$ & $\begin{array}{l}\text { No significant difference in } \\
\text { PA at } 3 \mathrm{mths}\end{array}$ \\
\hline $\begin{array}{l}\text { Alhassan et al., } 2012 \\
\text { United States [17] }\end{array}$ & RCT, 71 (3-5 yrs) & $6 \mathrm{mths}$ & $\begin{array}{l}\text { Daily } 30 \text { min structured lessons focusing on } \\
\text { locomotor and movement skills }\end{array}$ & $\begin{array}{c}\text { Primary/ } \\
\text { Accelerometers }\end{array}$ & $\begin{array}{l}\text { Significant difference in TPA } \\
\text { and SB during preschool } \\
\text { hours at } 6 \text { mths }\end{array}$ \\
\hline $\begin{array}{l}\text { Alhassan et al., 2013 } \\
\text { United States [18] }\end{array}$ & $\begin{array}{c}\text { Pilot cluster RCT, } 67 \text { (3-5 } \\
\text { yrs) }\end{array}$ & 4 wks & $\begin{array}{l}30 \text { min outdoor structured curriculum based } \\
\text { lesson, } 3 \text { times/wk during play time }\end{array}$ & $\begin{array}{c}\text { Primary/ } \\
\text { Accelerometers }\end{array}$ & $\begin{array}{c}\text { No significant difference in } \\
\text { PA at } 4 \text { wks }\end{array}$ \\
\hline $\begin{array}{l}\text { Annesi et al., } 2013 \\
\text { United States [19] }\end{array}$ & $\begin{array}{l}\text { Quasi-experimental, } 338 \\
\text { (3-5 yrs) }\end{array}$ & 8 wks & $\begin{array}{c}\text { Daily } 30 \text { min structured GMS lessons, } \\
\text { long-term and short-term goal setting for } \\
\text { children }\end{array}$ & $\begin{array}{l}\text { Primary/ } \\
\text { Accelerometers }\end{array}$ & $\begin{array}{l}\text { Significant difference for } \\
\text { MVPA and VPA at } 8 \text { wks }\end{array}$ \\
\hline $\begin{array}{l}\text { Bellows et al., 2013 } \\
\text { United States [20] }\end{array}$ & RCT, 201 (3-5 yrs) & 18 wks & $\begin{array}{c}20 \text { teacher-led activities focusing on GMS, } 4 \\
\text { days/wk for } 18 \text { wks }+12 \text { weeks nutrition } \\
\text { program }\end{array}$ & $\begin{array}{l}\text { Primary/ } \\
\text { Accelerometers }\end{array}$ & $\begin{array}{l}\text { No significant difference in } \\
\text { PA at } 18 \text { wks }\end{array}$ \\
\hline $\begin{array}{l}\text { Bonvin et al., } 2013 \\
\text { Switzerland [21] }\end{array}$ & Cluster RCT, 373 (2-4 yrs) & $8 \mathrm{mths}$ & $\begin{array}{l}\text { Daily PA period, rearrangement of indoor } \\
\text { and outdoor play spaces, } \$ 1500 \text { for } \\
\text { rearrangement of built environment }\end{array}$ & $\begin{array}{l}\text { Primary/ } \\
\text { Accelerometers }\end{array}$ & $\begin{array}{c}\text { No significant difference in } \\
\text { PA at } 18 \mathrm{wks}\end{array}$ \\
\hline $\begin{array}{l}\text { Cardon et al., } 2009 \\
\text { Belgium [22] }\end{array}$ & RCT, 583 (4-5 yrs) & $6 \mathrm{wks}$ & $\begin{array}{l}\text { Four interventions: } \\
\text { (1) play equipment, (2) markings, (3) play } \\
\text { equipment and markings, (4) control }\end{array}$ & $\begin{array}{l}\text { Primary/ } \\
\text { Accelerometers }\end{array}$ & $\begin{array}{l}\text { No significant difference in } \\
\text { PA at } 6 \mathrm{wks}\end{array}$ \\
\hline $\begin{array}{l}\text { De Bock et al., } 2010 \\
\text { Germany [23] }\end{array}$ & RCT, 826 (4-6 yrs) & $9 \mathrm{mths}$ & $\begin{array}{l}\text { Gym lessons (duration and frequency not } \\
\text { specified) }\end{array}$ & $\begin{array}{c}\text { Primary/ } \\
\text { Accelerometers }\end{array}$ & $\begin{array}{l}\text { Significant difference for TPA } \\
\text { at } 9 \mathrm{mths}\end{array}$ \\
\hline $\begin{array}{c}\text { De Craemer et al., } 2014 \\
\text { Belgium [24] }\end{array}$ & RCT, 472 (4-6 yrs) & $\begin{array}{c}24 \mathrm{wks} \\
1 \mathrm{yr}\end{array}$ & $\begin{array}{l}1 \mathrm{~h} \text { structured lesson once/wk. Classroom } \\
\text { activities and excursions. Rearrangement of } \\
\text { indoor classroom play space }\end{array}$ & $\begin{array}{c}\text { Primary/ } \\
\text { Accelerometers }\end{array}$ & $\begin{array}{l}\text { Significant difference for VPA } \\
\text { during after-school hours at } 1 \\
\text { yr }\end{array}$ \\
\hline $\begin{array}{l}\text { Eliakim et al., } 2007 \\
\text { Israel [34] }\end{array}$ & Cluster RCT, 101 (5-6 yrs) & 16 wks & $\begin{array}{l}\text { Educational sessions with games, printed } \\
\text { information, } 45 \text { min PA sessions } 6 \\
\text { days/week; exercise circuit (indoors and } \\
\text { outdoors) with mostly endurance activities, } \\
\text { some coordination and flexibility, and } \\
\text { additional nutrition education component }\end{array}$ & $\begin{array}{l}\text { Secondary/ } \\
\text { Pedometers }\end{array}$ & $\begin{array}{l}\text { Significant difference daily } \\
\text { steps for entire day, during } \\
\text { school hours and after school } \\
\text { significant difference in } \\
\text { fitness at } 16 \text { wks }\end{array}$ \\
\hline $\begin{array}{l}\text { Finch et al., 2014 } \\
\text { Australia [25] }\end{array}$ & Cluster RCT, 245 (3-5 yrs) & $4 \mathrm{mths}$ & $\begin{array}{c}\text { Daily } 20 \text { min structured GMS session, staff } \\
\text { role modelling, rearrangement of indoor and } \\
\text { outdoor environment }\end{array}$ & $\begin{array}{l}\text { Primary/ } \\
\text { Pedometers }\end{array}$ & $\begin{array}{l}\text { No significant difference in } \\
\text { PA at } 4 \text { mths }\end{array}$ \\
\hline
\end{tabular}


Table 1. Cont

\begin{tabular}{|c|c|c|c|c|c|}
\hline Reference and Country & $\begin{array}{l}\text { Design, Sample at } \\
\text { Baseline }\end{array}$ & $\begin{array}{l}\text { Length and } \\
\text { Follow-Up }\end{array}$ & Intervention & $\begin{array}{l}\text { PA Outcome/PA } \\
\text { Measurement }\end{array}$ & PA Findings \\
\hline $\begin{array}{l}\text { Fitzgibbon et al., 2005 } \\
\text { United States [35] }\end{array}$ & Cluster RCT, 409 (3-5 yrs) & $\begin{array}{c}14 \text { wks } \\
1 \text { and } 2 \text { yrs }\end{array}$ & $\begin{array}{l}40 \text { min education session } 3 \text { days/wk ( } 20 \mathrm{~min} \\
\text { for nutrition, } 20 \text { min for aerobic activity) }\end{array}$ & $\begin{array}{c}\text { Secondary/ } \\
\text { Parent-proxy report }\end{array}$ & $\begin{array}{l}\text { No significant difference in } \\
\text { PA at } 1 \text { or } 2 \text { yrs }\end{array}$ \\
\hline $\begin{array}{l}\text { Fitzgibbon et al., 2006 } \\
\text { United States [36] }\end{array}$ & Cluster RCT, 401 (3-5 yrs) & $\begin{array}{c}14 \text { wks } \\
1 \text { and } 2 \text { yrs }\end{array}$ & $\begin{array}{l}40 \text { min education session } 3 \text { days } / \text { wk ( } 20 \mathrm{~min} \\
\text { for nutrition, } 20 \text { min for aerobic activity) }\end{array}$ & $\begin{array}{c}\text { Secondary/ } \\
\text { Parent-proxy report }\end{array}$ & $\begin{array}{l}\text { No significant difference in } \\
\text { PA at } 1 \text { or } 2 \text { yrs }\end{array}$ \\
\hline $\begin{array}{l}\text { Fitzgibbon et al., 2011 } \\
\text { United States [37] }\end{array}$ & Cluster RCT, 190 (3-5 yr) & 14 wks & $\begin{array}{c}20 \text { min structured lesson related to PA, } \\
\text { twice/wk }\end{array}$ & $\begin{array}{l}\text { Secondary/ } \\
\text { Accelerometers }\end{array}$ & $\begin{array}{l}\text { Significant difference for } \\
\text { MVPA, VPA at } 14 \text { wks }\end{array}$ \\
\hline $\begin{array}{l}\text { Froehlich Chow et al., } \\
2016 \\
\text { Canada [26] }\end{array}$ & RCT, 69 (4.9 yrs) & $48 \mathrm{wks}$ & $\begin{array}{l}\text { Multi-component focusing on food and } \\
\text { physical activity }\end{array}$ & $\begin{array}{c}\text { Primary/ } \\
\text { Accelerometers }\end{array}$ & $\begin{array}{l}\text { Significant difference for } \\
\text { MVPA at } 48 \mathrm{wks}\end{array}$ \\
\hline $\begin{array}{l}\text { Jones et al., } 2011 \\
\text { Australia [27] }\end{array}$ & $\mathrm{RCT}, 97$ (4.1 yrs) & $20 \mathrm{wks}$ & $\begin{array}{l}\text { Structured } 20 \text { min activities to improve GMS } \\
3 \text { times/wk + teacher engagement with } \\
\text { children during unstructured time }\end{array}$ & $\begin{array}{c}\text { Primary/ } \\
\text { Accelerometers }\end{array}$ & $\begin{array}{c}\text { No significant difference in } \\
\text { PA at } 20 \text { wks }\end{array}$ \\
\hline $\begin{array}{l}\text { Jones et al., } \\
\quad 2016 \\
\text { Australia [28] }\end{array}$ & RCT, 150 (4.0 yrs) & $6 \mathrm{mths}$ & $\begin{array}{l}\text { Structured } 20 \text { min activities to improve GMS } \\
3 \text { times/wk + teacher engagement with } \\
\text { children during unstructured time }\end{array}$ & $\begin{array}{c}\text { Primary/ } \\
\text { Accelerometers }\end{array}$ & $\begin{array}{l}\text { No significant difference in } \\
\text { PA at mths }\end{array}$ \\
\hline $\begin{array}{l}\text { Nemet et al., 2011, } 2013 \\
\text { Israel [38] }\end{array}$ & Cluster RCT, 795 (3-6 yrs) & $\begin{array}{l}1 \mathrm{yr} \\
2 \mathrm{yrs}\end{array}$ & $\begin{array}{c}\text { Educational sessions with games, books, } \\
\text { printed information, } 45 \text { min PA session } 6 \\
\text { times/wk }\end{array}$ & $\begin{array}{l}\text { Secondary/ } \\
\text { Accelerometers }\end{array}$ & $\begin{array}{l}\text { Significant difference in } \\
\text { fitness (measure of PA) at } 1 \\
\text { and } 2 \text { yrs }\end{array}$ \\
\hline $\begin{array}{l}\text { O'Dwyer et al., } 2013 \\
\text { United Kingdom [29] }\end{array}$ & Cluster RCT, 218 (3-5 yrs) & $\begin{array}{l}6 \mathrm{wks} \\
6 \mathrm{mths}\end{array}$ & $1 \mathrm{~h}$ structured active play sessions once/wk & $\begin{array}{c}\text { Primary/ } \\
\text { Accelerometers }\end{array}$ & $\begin{array}{l}\text { No significant difference in } \\
\text { PA at } 6 \mathrm{mths}\end{array}$ \\
\hline $\begin{array}{l}\text { Parish et al., 2007 } \\
\text { United States [30] }\end{array}$ & $\begin{array}{l}\text { Quasi-experimental, } 21 \\
\text { (2.6 yrs) }\end{array}$ & Unknown & $2 \times 30$ minute play sessions/wk & $\begin{array}{c}\text { Primary/ } \\
\text { Heart rate monitors }\end{array}$ & $\begin{array}{l}\text { Significant difference in heart } \\
\text { rate (measure of PA) }\end{array}$ \\
\hline $\begin{array}{l}\text { Puder et al., 2011 } \\
\text { Switzerland [31] }\end{array}$ & Cluster RCT, 421 (4-6 yrs) & $\begin{array}{l}1 \mathrm{yr} \\
2 \mathrm{yrs}\end{array}$ & $\begin{array}{l}4 \times 45 \text { min PA sessions/wk, } 22 \text { sessions on } \\
\text { healthy nutrition, media use and sleep. }\end{array}$ & $\begin{array}{c}\text { Primary/ } \\
\text { Accelerometers }\end{array}$ & $\begin{array}{l}\text { Significant difference in } \\
\text { fitness (PA measure) at } 1 \mathrm{yr}\end{array}$ \\
\hline $\begin{array}{l}\text { Reilly et al., } 2006 \\
\text { Scotland [39] }\end{array}$ & Cluster RCT, 545 (4.2 yrs) & $\begin{array}{c}24 \mathrm{wks} \\
1 \mathrm{yr}\end{array}$ & $\begin{array}{l}30 \text { min enhanced PA program, } 3 \text { days/wk, } \\
\text { posters }\end{array}$ & $\begin{array}{c}\text { Secondary/ } \\
\text { Accelerometers }\end{array}$ & $\begin{array}{l}\text { No significant difference in } \\
\text { PA at } 24 \mathrm{wks} \text { and } 1 \mathrm{yr}\end{array}$ \\
\hline $\begin{array}{l}\text { Roth et al., } \\
\quad 2015 \\
\text { Germany [32] }\end{array}$ & RCT, 709 (4.7 yrs) & $1 \mathrm{yr}$ & $\begin{array}{c}5 \times 30 \text { min PA sessions/wk, PA homework } \\
\text { cards and seasonal letters with games over } \\
\text { the holidays }\end{array}$ & $\begin{array}{c}\text { Primary/ } \\
\text { Accelerometers }\end{array}$ & $\begin{array}{l}\text { Significant difference in } \\
\text { MVPA at } 12 \text { months }\end{array}$ \\
\hline $\begin{array}{l}\text { Trost et al., } 2008 \\
\text { United States [33] }\end{array}$ & RCT, 42 (3-5 yrs) & $8 \mathrm{wks}$ & $\begin{array}{c}10 \text { min lesson, } 2 \text { days/wk for } 8 \text { weeks, } \\
\text { integrated PA into other key learning } \\
\text { experiences }\end{array}$ & $\begin{array}{c}\text { Primary/ } \\
\text { Accelerometers }\end{array}$ & $\begin{array}{l}\text { Significant difference in } \\
\text { MVPA in classroom and } \\
\text { outside for wks } 7 \text { and } 8\end{array}$ \\
\hline
\end{tabular}


In the majority of interventions, educators were encouraged to provide additional time for children to spend in physical activity (either structured or unstructured physical activity learning experiences). In most studies, children were encouraged to spend between 20 and $45 \mathrm{~min}$ in additional physical activity, two or three times a week. A small number of studies involved modifications to the indoor environment only [24], the indoor and outdoor environments [21,25], or the outdoor environment only [22]. One study provided funding to the intervention centers for the purchase of the mobile equipment and for the rearrangement of the environments to make them more activity-friendly (no further details provided) [21].

Most (87\%) interventions were facilitated by educators. A small number of interventions were co-led by researchers and educators. For example, Eliakim et al.'s [34] intervention was led by a professional youth coach for two days, and then by the educators for the other days. Similarly, the study by Nemet et al. [38] was led by a professional youth coach once a week and the educator on the other days. Alhassan et al.'s [18] intervention was exclusively facilitated by researchers, although it was helped by the educators, and De Bock et al.'s [23] study was led exclusively by external gym trainers. In general, educators received professional development in the aims of the intervention and the intervention components prior to the start of the intervention. All professional development was facilitated face-to-face; however, the intensity and frequency of the training and the resources provided varied. For example, Alhassan et al. [18], Bonvin et al. [21], and Finch et al. [25] included four to eight hours of educator professional development. Various resources were provided as part of the professional development, such as prepared lesson plans or resources (e.g., newsletters, posters, music CD, stickers, child achievement cards) [18-20,24], equipment $[17,18,24,31]$, and additional face-to-face support $[21,25,31]$.

The majority of studies used accelerometers to assess physical activity, which were worn for a number of hours or days [16-24,26-33,37-39]. Cut points used to categorize physical activity were "Pate" [40] and "Sirard" [41] references. Other instruments used to measure physical activity included pedometers (steps/day) [25,34], heart rate monitors [30], and parent-proxy report [34,35].

Of the 18 studies with physical activity as the main outcome, eight $(44 \%)$ reported significant changes in physical activity outcomes at the end of the intervention $[17,19,23,24,26,30,31,33]$. Significant changes in moderate- to vigorous-intensity physical activity (MVPA) and vigorous-intensity physical activity (VPA) were reported for Annesi et al. [19], De Craemer et al. [24] and Trost et al. [33]. Significant changes in total physical activity was reported for Alhassan et al. [17] and De Bock et al. [23]. Puder et al. [31] reported significant changes in fitness levels between the intervention group and the control group. Of the six studies that included physical activity as a secondary outcome, half $(50 \%)$ reported significant changes in physical activity levels [34,37,38]. Fitzgibbon et al. [37] reported significant changes for MVPA and VPA between the intervention group and the control group, whereas Nemet et al. [38] and Eliakim et al. [34] reported significant changes in the number of steps and fitness levels, respectively.

\section{Discussion}

This paper aimed to provide a broad sweeping picture of previous ECEC-based physical activity interventions and highlight some similarities and differences between studies. On the whole, there were very few consistent characteristics between the studies, with studies varying in design, sample size, and length of intervention. However, two characteristics were consistent in all interventions: (1) the provision of additional time for physical activity for children each week, and (2) the participation of educators in professional development. Given the consistency of these characteristics, innovative, creative, and engaging mechanisms for ensuring that these components are prioritized in future interventions may be of benefit.

Three main research gaps were identified: (1) the lack of interventions in infants and toddlers; (2) professional development delivery methods (e.g., face-to-face, online, blended); and (3) the need for longer-term assessments. Despite physical activity being an important component of holistic child 
development and a behavior that should be encouraged from birth [1,42], all but one study had a mean participant age between 3-5 years [30]. This may be due to educators and researchers thinking that physical activity learning experiences are more relevant for older children, as these children have increased movement and cognitive abilities when compared to children aged 0-3 years. Despite this, it is still critically important programs for children aged 0-3 years provide a balance of child-initiated and adult-led experiences (all of which constitutes a play-based curriculum) [43]. Such interventions would need to be age- and developmentally-appropriate, and thus may "look" different from those implemented for older children. For example, the inclusion of "tummy time" and crawling activities would be a key component in interventions targeting younger children.

Professional development received by educators in all ECEC-based interventions reviewed was facilitated face-to-face. This type of professional development is widely used within the ECEC sector; however, it is associated with a number of limitations. For example, the limited transfer of knowledge [44] and a "top-down approach", which often results in not meeting the needs and wants of educators [45-48]. Alternate methods of professional development, such as online professional development, mentoring, coaching, and blended (involving both face-to-face and online components) professional development may be more viable for the ECEC sector. To date, only one study comprising blended professional development for the ECEC sector has been evaluated: positive changes in child-level data and center-level physical activity data were reported [49]. This method of delivery seems to hold promise for the ECEC sector; however, additional studies are needed to support these initial findings [49].

Only six studies assessed physical activity outcomes at one year [24,31,32,35,36,38,39], and only four studies assessed physical activity outcomes more than one year [31,35,36,38]. Longer follow-up periods are recommended, as adequate "soak time" is needed for change to become part of the ECEC routine, and for behaviors to change and new norms to be re-established [50]. Educators need the time to process, discuss, and reflect on the new information offered in professional development sessions. Additionally, they need time to critically reflect on current practices, and devise sustainable methods of change within their centers, with their staff that are consistent with their pedagogical practices [51]. The children also need time to adapt to new routines and learning experiences, and to become comfortable with these experiences. Change within the ECEC sector is no different from other educational sectors; it is typically met by educators with resistance and considerable effort, therefore support is needed to ensure that long-term changes are implemented and sustained [51]. The best method of support to enable long-term change in ECEC settings remains unknown; however, a recent study suggested that telephone support or ongoing mentoring programs that involve site visits may be the most preferred and successful option for the ECEC sector, at least in high-income countries like Australia [52]. Additional research is needed to determine the best support mechanisms for the ECEC sector that will ensure that change in children's physical activity behaviors are maintained.

\subsection{Trends}

The ECEC environment has changed significantly since 2000, as new national and international regulations have been introduced, making it a complex environment for the implementation of interventions [43]. As new regulations have been enforced, the demands on educators have exponentially increased, with increased documentation required and shifts in job description for senior staff (i.e., higher-qualified educators are now devoting time to business development rather than teaching and mentoring) $[53,54]$.

Given the complexity and uniqueness of the ECEC environment [54], several additional trends may need to be considered in the formative stages of future interventions. These trends are not explicitly discussed in the papers reviewed (see Results section), but are based on current evidence and the expert opinion of researchers and practitioners working in the sector internationally over a number of years. ECEC environments, at least within the Australian context, have an exceptionally high turnover of staff, which makes transfer of knowledge and consistent pedagogical practices difficult [51]. 
Future ECEC-based physical activity interventions need to consider how to maximize knowledge transfer during the implementation period (and beyond) of an intervention. Ongoing and online professional development may be one viable method of ensuring consistent, high-quality pedagogical practice [49].

Shaping or reshaping educators' perceptions in relation to physical activity may also be an important area to investigate in future interventions. It is well-established that educators have a critical role in shaping the behaviors and patterns of the children in their care [55]. Some studies have shown that educator's behaviors positively influence physical activity behaviors of children $[3,56,57]$. That is, where educators provide positive prompts in relation to physical activity activities or role model positive physical-activity behaviors, children are more consistently more active [56,57]. In contrast, and perhaps more common, other studies suggest that the main role of educators in relation to physical activity is a passive supervisory role, and that young children are sufficiently active during ECEC hours and do not need intentional physical activity learning experiences [5,58]. Educators also shy away from providing intentional physical activity experiences, due to their own low levels of self-efficacy in this area [59]. Several studies have highlighted that educators do not feel comfortable or knowledgeable enough about physical activity or know what experiences to offer the children, therefore tend not to offer any $[59,60]$. Allocating time to inform educators of the vital importance of physical activity in children's development and discussing examples of successful and engaging physical activity learning experiences may be a critical component of ECEC-based interventions that focus on physical activity or are inclusive of a physical activity component. Physical activity for young children is often (mis)conceptualized by educators as structured activities or activities that just involve running or jumping at high intensity. However, for preschool children, physical activity is a broad term that should be inclusive of risky play; fine and gross motor skills; social interactions; movement vocabulary; and engagement and communication between children, their families, and educators [61]. It is much more than the traditional perceptions of physical activity.

Physical activity is often underrepresented in both curriculums and current practice. Other key learning domains, such as the cognitive and social/emotional domains, seem to take higher priority. This may be attributed to the greater diagnosed or undiagnosed needs of children in ECEC settings, where children with higher social and emotional needs require more attention from educators, and thus more time is spent specifically on enhancing the social and emotional needs of children. Certainly within the Australian environment, there is a push for heightened child agency (i.e., supporting children's rights within the learning environment), optimizing child self-regulation and supporting children affected by trauma-aspects that align within the social and emotional domains, therefore offering limited time for other domains, such as the physical [43]. The reduced emphasis on the physical learning domain may also be a consequence of the requirements for educators to provide holistic comprehensive programs. For example, educators are required to integrate science, technology, engineering, and mathematics (STEM) learning experiences, as well as learning experiences that are inclusive of sustainability and cultural competence components, health and hygiene, and child protection [43]. In some countries, the overarching push for children to become "school-ready" well before they enter school [62] may also influence the time spent in high-quality physical activity learning experiences. In such countries, the emphasis is on learning to read and write to ensure that children are adeptly prepared to transition to formal schooling [62]. However, school readiness is actually about the ability for children to develop independence, follow instructions, form friendships and socialize, listen, complete an experience or task, communicate, and engage and interact with their peers and educators $[63,64]$. It is also about the appropriate development of fine and gross motor skills and strong core muscle development. Many of these attributes are developed through the participation of age-appropriate, physically active, inclusive intentional learning experiences rather than academic-based skills [63,64].

The administrative burden of educators has exponentially increased in the past decade [54]. Whilst educators have always been required to provide documentation on their educational programs 
and the developmental outcomes of children, they are now also required to adhere to comprehensive assessment and compliance requirements [54]. For example, in Australia, ECECs must gather evidence and complete documentation across seven quality areas outlined under the National Quality Standards [43], which involves completing an ongoing Quality Improvement Plan and providing evidence of how educators are critically reflecting on policies and practices across the afore-mentioned areas. Furthermore, in many countries, educators are required to be in constant communication with parents throughout the day via daily electronic notice boards (e.g., Kinderloop (https://kinderloop.com)) so that parents can view the learning experiences their children participate in throughout the day [65]. These added responsibilities now have the potential to deter educators away from their core business, which is teaching children [65].

\subsection{Recommendations}

In light of the studies discussed, and considering the gaps in the current evidence and the current trends within the international ECEC sector, future ECEC-based physical activity interventions could consider the following four recommendations. Recommendations 1 and 2 are based on data extracted from the papers discussed in the Results section, and recommendations 3 and 4 are based on current evidence from broader ECEC literature, which is applicable to ECEC-based physical activity interventions. Future ECEC-based interventions could consider:

(1) The provision of high-quality professional development for educators prior, during, and beyond the intervention phase. Given the low competence and confidence levels of most educators in the area of physical activity, explicit professional development should be a priority. The professional development should be delivered by experts with experience working within the ECEC sector, and should include information on the critical role of the physical domain in child development. Furthermore, providing additional training to pre-service educators in the area of the physical domain is important.

(2) Interventions that are "outside the box". The majority of ECEC-based physical activity interventions have been standard in intervention design and delivery; they have involved face-to-face professional development, a prescriptive physical activity component for the children, and a few suggestions of additional resources. Future interventions should start to think outside the box with regard to intervention components and delivery. The following questions might be helpful as future interventions are planned: Can blended professional development be used? What role can technology play in physical activity interventions? Is it important to consider the health, well-being, and physical activity levels of the educators? Can interventions target educators' physical activity? Can interventions incorporate a combination of intervention components-for example, structured physical activity learning experiences, outdoor marking, and energy breaks? How can physical activity be integrated into all aspects of the normal routine? How can physical activity experiences be extended, expanded, or enhanced [66] in ECEC settings?

(3) Meaningful and trustworthy collaborations between educators and researchers. Developing collaborative professional relationships between researchers and educators can help maximize children's physical activity outcomes. A recent paper suggests the successful collaboration involves researchers spending time learning about the ECEC environment and presenting research findings in an easily interpretable manner to educators [59], thereby ensuring that research is translated into relatable practical strategies that enable educators to critically reflect on current practices. Furthermore, the importance of researchers understanding the profound place of relationships within the ECEC sector and the importance of including educators in the research process were also highlighted as being critical [59]. Trustworthy and meaningful relationships between educators and researchers are particularly paramount for the success of intervention studies, which often require additional responsibilities from educators and change within their centers [59].

(4) The influence of the quality of the ECEC environment. It is well-established that the quality of the ECEC environment has a significant influence on children's outcomes, both in the short and long term [67]. Several key studies, such as the Effective Pre-school, Primary and Secondary Education 
Project [67], have shown that higher quality ECEC environments results in better cognitive, social, and behavioral outcomes, immediately (ages 3-5 years) and several years later (e.g., at ages 11 and 16) [55]. In fact, literacy outcomes at age 11 are influenced more by the quality of the ECEC environment than the family's income, father's education, or the quality of the primary school [55]. Thus, future interventions should consider assessment of the quality of the environment in relation to physical activity, and consider how this could be improved through intervention components. To date, there are relatively few reliable and valid instruments available that assess the quality of the ECEC environment in relation to physical activity. The MOVERS Scale [61], which was published in 2017, is the first instrument to assess the product and process quality of the ECEC environment in relation to physical activity. It has four sub-scales: curriculum, environment, and resources for physical development; pedagogy for physical development; supporting physical activity and critical thinking; and parents/guardians and staff [61]. The MOVERS Scale focuses on the influence of the educators with regard to physical activity, as well as physical activity learning experiences offered to the children. High-quality instruments that measure the quality of the ECEC environment in relation to physical activity should be considered as a measure in future interventions.

This discussion provides a broad summary of ECEC-based physical activity interventions, and highlights some of the similarities and differences between key studies. The discussion and recommendations should be considered in light of the that fact that the studies discussed were not exhaustive, but rather a representative sample of the current evidence. Single-group pre-test/post-test studies, studies specific to family day care, or those that focused on adherence to policies [68] were not included. Lessons and recommendations can also be ascertained from such studies. A formal review of reviews was not conducted. A formal review of reviews would have provided further evidence of pooled data in relation to successful interventions, and would have provided information pertaining to the methodological quality of the studies.

To date, broad sweeping recommendations for future ECEC-based interventions have been provided. For example, future interventions should consider longer-term follow-up, multi-strategy interventions that include changes in the physical activity environment, reporting of cost-effectiveness, and the consideration of sustainability [10,11]. Future ECEC-based interventions are certainly important to contemplate, but perhaps a broader view also needs to be considered. Perhaps time needs to be spent advocating for additional focus of the physical domain in training programs (such as undergraduate degrees, diplomas, and certificate training). How can policy be influenced to highlight the importance of the physical domain, physical development, and physical activity for young children? How can national training bodies (e.g., the Early Childhood Training and Resource Centre in Australia) be encouraged to prioritize (or at least include) professional development in this area? What intervention strategies can be translated into policy and practice, and be rolled out throughout countries?

With the release of recent physical activity guidelines for the early years from a number of countries (including Australia, Canada, the United Kingdom, and South Africa [69-72]), as well as those released from the World Health Organization [73], it is clear that the promotion of physical activity must continue to be a global priority to ensure the health and wellbeing of young children now and in the future. The ECEC environment, although challenging and complex, needs to continue to be a key environment for the promotion of physical activity. ECEC-based physical activity interventions should continue to be an important area of focus and funding simultaneously with broader advocacy approaches.

\section{Conclusions}

Physical activity promotion and participation is important from a young age for optimum health and wellbeing. ECECs have a critical role to play in the promotion of physical activity behaviors; however, during the design phase of future interventions the current issues and trends of ECECs need to be seriously considered in order for effective ECEC-based physical activity interventions to be successful. Interventions, which are sustainable and transferable, should be a priority. 
Author Contributions: Conceptualization, R.A.J. and A.D.O.; methodology R.A.J., E.S.-S., M.P., and A.D.O.; data extraction, R.A.J., E.S.-S., and M.P.; writing—original draft presentation, R.A.J.; writing—review and editing, R.A.J., E.S.-S., M.P., and A.D.O.; project administration, R.A.J. and A.D.O.

Funding: This research received no external funding.

Conflicts of Interest: The authors declare no conflict of interest.

\section{References}

1. Carson, V.; Lee, E.-Y.; Hewitt, L.; Jennings, C.; Hunter, S.; Kuzik, N.; Stearns, J.A.; Unrau, S.P.; Poitras, V.J.; Gray, C. Systematic review of the relationships between physical activity and health indicators in the early years (0-4 years). BMC Public Health 2017, 17, 854.

2. Jones, R.A.; Hinkley, T.; Okely, A.D.; Salmon, J. Tracking physical activity and sedentary behavior in childhood: A systematic review. Am. J. Prev. Med. 2013, 44, 651-658. [CrossRef] [PubMed]

3. Vanderloo, L.M.; Tucker, P.; Johnson, A.M.; van Zandvoort, M.M.; Burke, S.M.; Irwin, J.D. The influence of centre-based childcare on preschoolers' physical activity levels: A cross-sectional study. Int. J. Environ. Res. Public Health 2014, 11, 1794-1802. [CrossRef] [PubMed]

4. Organization for Economic Cooperation and Development. Family Database, 2014n. PF3.2: Enrolment in Childcare and Pre-Schools; OECD-Social Policy Division-Directorate of Employment, Labour and Social Affairs; OECD: Paris, France, September 2019.

5. Ellis, Y.G.; Cliff, D.P.; Janssen, X.; Jones, R.A.; Reilly, J.J.; Okely, A.D. Sedentary time, physical activity and compliance with IOM recommendations in young children at childcare. Prev. Med. Rep. 2017, 7, $221-226$. [CrossRef] [PubMed]

6. Engel, A.; Broderick, C.; van Doorn, N.; Hardy, L.; Parmenter, B. Exploring the relationship between fundamental motor skill interventions and physical activity levels in children: A systematic review and meta-analysis. Sport Med. 2018, 48, 1845-1857. [CrossRef] [PubMed]

7. Timmons, B.W.; LeBlanc, A.; Carson, V.; Gorber, S.; Dillman, C.; Janssen, I.; Kho, M.E.; Spence, J.C.; Stearns, J.A.; Tremblay, M.S. Systematic review of physical activity and health in the early years (aged 0-4 years). Appl. Physiol. Nutr. Metab. 2012, 37. [CrossRef]

8. Ward, S.; Belanger, M.; Donovan, D.; Carrier, N. Systematic review of the relationship between childcare educators' practices and preschoolers' physical activity and eating behaviors. Obes. Res. 2015, 16, 1055-1070. [CrossRef]

9. Gordon, E.S.; Tucker, P.; Burke, S.M.; Carron, A.V. Effectiveness of physical activity interventions for preschoolers: A meta-analysis. Res. Q. Exerc. Sport 2013, 84, 287-294. [CrossRef]

10. Finch, M.; Jones, J.; Yoong, S.L.; Wiggers, J.; Wolfenden, L. Effectiveness of centre-based childcare interventions in increasing child physical activity: A systematic review and meta-analysis for policy makers and practitioners. Obes. Rev. 2016, 17, 417-428. [CrossRef]

11. Zhou, Y.E.; Emerson, J.S.; Levine, R.S.; Kihlberg, C.J.; Hull, P.C. Childhood obesity prevention interventions in childcare settings: Systematic review of randomized and nonrandomized controlled trials. Am. J. Health Promot. 2014, 28, e92-e103. [CrossRef]

12. Morris, H.; Skouteris, H.; Edwards, S.; Rutherford, L. Obesity prevention interventions in early childhood education and care settings with parental involvement: A systematic review. Early Child Dev. Care 2015, 185, 1283-1313. [CrossRef]

13. Mehtälä, M.A.K.; Sääkslahti, A.K.; Inkinen, M.E.; Poskiparta, M.E.H. A socio-ecological approach to physical activity interventions in childcare: A systematic review. Int. J. Behav. Nutr. Phys. 2014, 11, 22. [CrossRef] [PubMed]

14. Temple, M.; Robinson, J.C. A systematic review of interventions to promote physical activity in the preschool setting. J. Spec. Pediatr. Nurs. 2014, 19, 274-284. [CrossRef] [PubMed]

15. Ward, D.S.; Vaughn, A.; McWilliams, C.; Hales, D. Physical activity at child care settings: Review and research recommendations. Am. J. Lifestyle Med. 2009, 3, 474-488. [CrossRef]

16. Alhassan, S.; Sirard, J.R.; Robinson, T.N. The effects of increasing outdoor play time on physical activity in Latino preschool children. Int. J. Pediatr. Obes. 2007, 2, 153-158. [CrossRef] [PubMed]

17. Alhassan, S.; Nwaokelemeh, O.; Ghazarian, M.; Roberts, J.; Mendoza, A.; Shitole, S. Effects of locomotor skill program on minority preschoolers' physical activity levels. Pediatr. Exerc. Sci. 2012, 24, 435-449. [CrossRef] 
18. Alhassan, S.; Nwaokelemeh, O.; Lyden, K.; Goldsby, T.; Mendoza, A. A pilot study to examine the effect of additional structured outdoor playtime on preschoolers' physical activity levels. Child Care Pract. 2013, 19, 23-35. [CrossRef]

19. Annesi, J.J.; Smith, A.E.; Tennant, G.A. Effects of the Start For Life treatment on physical activity in primarily African American preschool children of ages 3-5 years. Psychol. Health Med. 2013, 18, 300-309. [CrossRef]

20. Bellows, L.L.; Davies, P.L.; Anderson, J.; Kennedy, C. Effectiveness of a physical activity intervention for Head Start preschoolers: A randomized intervention study. Am. J. Occup. Ther. 2013, 67, 28-36. [CrossRef]

21. Bonvin, A.; Barral, J.; Kakebeeke, T.H.; Kriemler, S.; Longchamp, A.; Schindler, C.; Marques-Vidal, P.; Puder, J.J. Effect of a governmentally-led physical activity program on motor skills in young children attending child care centers: A cluster randomized controlled trial. Int. J. Behav. Nutr. Phys. Act. 2013, 10, 90. [CrossRef]

22. Cardon, G.; Labarque, V.; Smits, D.; De Bourdeaudhuij, I. Promoting physical activity at the pre-school playground: The effects of providing markings and play equipment. Prev. Med. 2009, 48, 335-340. [CrossRef] [PubMed]

23. De Bock, F.; Fischer, J.E.; Hoffmann, K.; Renz-Polster, H. A participatory parent-focused intervention promoting physical activity in preschools: Design of a cluster-randomized trial. BMC Public Health 2010, 10, 49. [CrossRef] [PubMed]

24. De Craemer, M.; De Decker, E.; Verloigne, M.; De Bourdeaudhuij, I.; Manios, Y.; Cardon, G. ToyBox-study group. The effect of a kindergarten-based, family-involved intervention on objectively measured physical activity in Belgian preschool boys and girls of high and low SES: The ToyBox-study. Int. J. Behav. Nutr. Phys. Act. 2014, 11, 38. [CrossRef] [PubMed]

25. Finch, M.; Wolfenden, L.; Morgan, P.J.; Freund, M.; Jones, J.; Wiggers, J. A cluster randomized trial of a multi-level intervention, delivered by service staff, to increase physical activity of children attending center-based childcare. Prev. Med. 2014, 58, 9-16. [CrossRef] [PubMed]

26. Froehlich Chow, A.; Leis, A.; Humbert, L.; Muhajarine, N.; Engler-Stringer, R. Healthy Start-Depart Sante: A pilot study of a multi-level intervention to increase physical activity, fundamental movement skills and healthy eating in rural childcare centres. Can. J. Public Health 2016, 107, e312-e318. [CrossRef] [PubMed]

27. Jones, R.A.; Riethmuller, A.; Hesketh, K.; Trezise, J.; Batterham, M.; Okely, A.D. Promoting fundamental movement skill development and physical activity in early childhood settings: A cluster randomized controlled trial. Pediatr. Exerc. Sci. 2011, 23, 600-615. [CrossRef] [PubMed]

28. Jones, R.A.; Okely, A.D.; Hinkley, T.; Batterham, M.; Burke, C. Promoting gross motor skills and physical activity in childcare: A translational randomized controlled trial. J. Sci. Med. Sport 2016, 19, 744-749. [CrossRef]

29. O’Dwyer, M.V.; Fairclough, S.J.; Ridgers, N.D.; Knowles, Z.R.; Foweather, L.; Stratton, G. Effect of a school-based active play intervention on sedentary time and physical activity in preschool children. Health Educ Res. 2013, 28, 931-942. [CrossRef]

30. Parish, L.E.; Rudisill, M.E.; St Onge, P.M. Mastery motivational climate: Influence on physical play and heart rate in African American toddlers. Res. Q. Exerc. Sport 2007, 78, 171-178. [CrossRef]

31. Puder, J.J.; Marques-Vidal, P.; Schindler, C.; Zahner, L.; Niederer, I.; Bürgi, F.; Ebenegger, V.; Nydegger, A.; Kriemler, S. Effect of multidimensional lifestyle intervention on fitness and adiposity in predominantly migrant preschool children (Ballabeina): Cluster randomised controlled trial. BMJ 2011, 343, d6195. [CrossRef]

32. Roth, K.; Kriemler, S.; Lehmacher, W.; Ruf, K.C.; Graf, C.; Hebestreit, H. Effects of a physical activity intervention in preschool children. Med. Sci. Sports Exerc. 2015, 47, 2542-2551. [CrossRef] [PubMed]

33. Trost, S.G.; Fees, B.S.; Dzewaltowski, D.A. Feasibility and efficacy of a "move and learn" physical activty curriculum in preschool children. J. Phys. Act. Health 2008, 5, 88-103. [CrossRef] [PubMed]

34. Eliakim, A.; Nemet, D.; Balakirski, Y.; Epstein, Y. The effects of nutritional-physical activity school-based intervention on fatness and fitness in preschool children. J. Pediatr. Endocrinol. Metab. 2007, 20, 711-718. [CrossRef] [PubMed]

35. Fitzgibbon, M.L.; Stolley, M.R.; Schiffer, L.; Van Horn, L.; KauferChristoffel, K.; Dyer, A. Two-year follow-up results for Hip-Hop to Health Jr.: A randomized controlled trial for overweight prevention in preschool minority children. J. Pediatr. 2005, 146, 618-625. [CrossRef]

36. Fitzgibbon, M.L.; Stolley, M.R.; Schiffer, L.; Van Horn, L.; KauferChristoffel, K.; Dyer, A. Hip-Hop to Health Jr. for Latino preschool children. Obesity 2006, 14, 1616-1625. [CrossRef] 
37. Fitzgibbon, M.L.; Stolley, M.R.; Schiffer, L.A.; Braunschweig, C.L.; Gomez, S.L.; Van Horn, L.; Dyer, A.R. Hip-Hop to Health Jr. Obesity Prevention Effectiveness Trial: Postintervention results. Obesity 2011, 19, 994-1003. [CrossRef]

38. Nemet, D.; Geva, D.; Eliakim, A. Health promotion intervention in low socioeconomic kindergarten children. J. Pediatr. 2011, 158, 796-801 e791. [CrossRef]

39. Reilly, J.J.; Kelly, L.; Montgomery, C.; Williamson, A.; Fisher, A.; McColl, J.H.; Lo Conte, R.; Paton, J.Y.; Grant, S. Physical activity to prevent obesity in young children: Cluster randomised controlled trial. BMJ 2006, 333, 1041. [CrossRef]

40. Pate, R.; Almeida, M.J.; McIver, K.L.; Pfeiffer, K.A.; Dowda, M. Validation and calibration of an accelerometer in preschool children. Obesity 2006, 14, 2000-2006. [CrossRef]

41. Sirard, J.R.; Trost, S.G.; Pfeiffer, K.A.; Dowda, M.; Pate, R.R. Calibration and evaluation of an objective measure of physical activity in preschool children. J. Phys. Act. Health 2005, 2, 345-357. [CrossRef]

42. Janssen, I.; LeBlanc, A.G. Systematic review of the health benefits of physical activity and fitness in school-aged children and youth. Int. J. Behav. Nutr. Phys. Act. 2010, 7, 40. [CrossRef] [PubMed]

43. Department of Education, Employment and Workplace Relations (DEEWR). Belonging, Being and Becoming: The Early Years Learning Framework for Australia; Australian Government: Canberra, Australia, 2009.

44. Yoong, S.L.; Williams, C.M.; Finch, M.; Wyse, R.; Jones, J.; Freund, M.; Wiggers, J.H.; Nathan, N.; Dodds, P.; Wolfenden, L. Childcare service centers' preferences and intentions to use a web-based program to implement healthy eating and physical activity policies and practices: A cross-sectional study. J. Med. Internet Res. 2015, 17. [CrossRef] [PubMed]

45. Buysse, V.; Winton, P.; Roth, B. Reaching consensus on a definition of professional development for the early childhood filed. Top. Early Child. Spec. Educ. 2009, 28, 235-243. [CrossRef]

46. Nuttall, J. The potential of developmental work research as a professional learning methodology in early childhood education. Contemp. Issues Early Child. 2013, 14, 201-211. [CrossRef]

47. Pianta, R. Standardized observation and professional development: A focus on individualized implementation and practices. In Critical Issues in Early Childhood Professional Development; Brookes: Baltimore, MD, USA, 2006; pp. 231-254.

48. Wood, E.; Bennett, N. Changing theories, changing practice: Exploring early childhood teachers' professional learning. Teach. Teach. Educ. 2000, 16, 635-647. [CrossRef]

49. Peden, M.; Eady, M.; Okely, A.; Patterson, K.; Batterham, M.; Jones, R. A blendedvintervention for educators in early childhood education and care settings targeting physical activity and healthy eating behaviors in young children: A cluster randomised stepped-wedge design. Early Child. Res. Q. 2019. under review.

50. Jones, R.A.; Sinn, N.; Campbell, K.J.; Hesketh, K.; Denney-Wilson, E.; Morgan, P.J.; Lubans, D.R.; Magarey, A. The importance of long-term follow-up in child and adolescent obesity prevention interventions. Int. J. Pediatr. Obes. 2011, 6, 178-181. [CrossRef]

51. Siraj, I.; Kingston, D.; Neilsen-Hewett, C.; Howard, S.; Melhuish, E.; de Rosnay, M.; Luu, B. Fostering Effective Early Learning Study. In Department of Education; NSW Government: Darlinghurst, Australia, 2017.

52. Strooband, K.F.; Stanley, R.M.; Okely, A.D.; Jones, R.A. Support to enhance level of implementation in physical activity interventions: An observational study. Australas. J. Early Child. 2018, 43, 25. [CrossRef]

53. Heikka, J.; Halttunen, L.; Waniganayake, M. Perceptions of early childhood education preofessionas on teacher leadership in Finland. Early Child. Dev. Care 2018, 2, 143-156. [CrossRef]

54. Haslip, M.; Gullo, D. The changing landscape of early chidhood education: Implications for policy and practice. Early Child. Educ. J. 2018, 46, 249-264. [CrossRef]

55. Siraj-Blatchford, I. Conceptualising progression in the pedagogy of play and sustained shared thinking in early childhood education: A Vygotskian perspective. Educ. Child Psychol. 2009, 26, 77-89.

56. Bower, J.K.; Hales, D.P.; Tate, D.F.; Rubin, D.A.; Benjamin, S.E.; Ward, D.S. The childcare environment and children's physical activity. Am. J. Prev. Med. 2008, 34, 23-29. [CrossRef] [PubMed]

57. Ward, D.; Hales, D.; Haverly, K.; Marks, J.; Benjamin, S.; Ball, S.; Trost, S. An instrument to assess the obesogenic environment of child care centers. Am. J. Health Behav. 2008, 32, 380-386. [CrossRef] [PubMed]

58. Strauss, R. Childhood obesity. Curr. Probl. Pediatr. 1999, 29, 1-29. [CrossRef]

59. Jones, R.A.; Gowers, F.L.; Stanley, R.M.; Okely, A.D. Enhancing the effectiveness of early childhood educators and researchers working together to achieve common aims. Australas. J. Early Child. 2017, 42, 81-84. [CrossRef] 
60. Dyment, J.; Coleman, B. The intersection of physical activity opportunities and the role of early childhood educators during outdoor play: Perceptions and reality. Australas. J Early Child. 2012, 37, 90. [CrossRef]

61. Archer, C.; Siraj, I. Movement Environment Rating Ccale (MOVERS) for 2-6-Year-Olds Provision: Improving Physical Development through Movement and Physical Activity.; Institute of Education Press: London, UK, 2017.

62. Bassok, D.; Latham, S.; Rorem, A. Is kindergarten the new first grade? AERA Open 2016, 2, 1-31. [CrossRef]

63. High, P.C. The Committee on Early Childhood; Adoption and Dependent Care and Council on School Health. School readiness. Pediatrics 2008, 121, e1008-e1015. [CrossRef]

64. Unicef. School Readiness. Available online: https://www.unicef.org/earlychildhood/files/Child2Child_ ConceptualFramework_FINAL(1).pdf (accessed on 24 September 2019).

65. Plumb, M. Multiple Perspectives on Understanding Innovation with IT in an Early Childhood Education and Care Organisation. Ph.D. Thesis, University of Wollongong, Wollongong, NSW, Australia, 2017.

66. Beets, M.W.; Okely, A.; Weaver, R.G.; Webster, C.; Lubans, D.; Brusseau, T.; Carson, R.; Cliff, D. The theory of expanded, extended and enhanced opportunities for youth physical activity promotion. Int. J. Behav. Nutr. Phys. Act. 2016, 13, 120. [CrossRef]

67. Sylva, K.; Melhuish, E.; Sammons, P.; Siraj-Blatchford, I.; Taggart, B. The Effective Pre-school, Primary and Secondary Education 3-14 Project (EPSSE 3-14); Final Report for the Key Stage 3 Phase influences on students' development from age 11-14; Research Report DfE-RR202; Department for Education: London, UK, 2012.

68. Wolfenden, L.; Neve, M.; Farrell, L.; Lecathelinais, C.; Bell, C.; Milat, A.; Wiggers, J.; Sutherland, R. Physical activity policies and practices of childcare centres in Australia. J. Paediatr. Child Health 2011, 47, 73-76. [CrossRef]

69. Okely, A.; Ghersi, D.; Hesketh, K.; Santos, R.; Loughran, S.; Cliff, D.; Shilton, T.; Grant, D.; Jones, A.; Stanley, R.; et al. A collaborative approach to adopting/adapting guidelines-The Australian 24-Hour Movement Guidelines for the early years (Birth to 5 years): An integration of physical activity, sedentary behavior, and sleep. BMC Public Health 2017, 17, 869. [CrossRef] [PubMed]

70. Tremblay, M.; Chaput, J.; Adamo, K.; Aubert, S.; Barnes, J.; Choquette, L.; Duggan, M.; Faulkner, G.; Goldfield, G.; Gray, C.; et al. Canadian 24-Hour Movement Guidelines for the Early Years (0-4 years): An Integration of Physical Activity, Sedentary Behaviour, and Sleep. BMC Public Health 2017, 17, 874. [CrossRef] [PubMed]

71. Reilly, J.; Hughes, A.; Janssen, X.; Hesketh, K.; Livinsgtone, S.; Hill, C.; Kipping, R.; Draper, C.; Okely, A.; Martin, A. GRADE ADOLOPMENT process to develop 24-hour movement behavior recommendations and physical activity guidelines for the under $5 \mathrm{~s}$ in the UK, 2019. J. Phys. Act. Health 2019, in press.

72. Moving, Playing, Sleeping: Starting Early with Healthy Habits. Available online: https://www.laureus.co.za/ moving-playing-sleeping-starting-early-with-healthy-habits/ (accessed on 22 November 2019).

73. Bull, F.; Willumsen, J. Developing global 24-hour movement guidelines for the Early Years. J. Phys. Act. Health 2018, 15, S204.

(C) 2019 by the authors. Licensee MDPI, Basel, Switzerland. This article is an open access article distributed under the terms and conditions of the Creative Commons Attribution (CC BY) license (http://creativecommons.org/licenses/by/4.0/). 